\title{
PENGARUH PEMBERIAN ASAM HUMAT (BERASAL DARI BATUBARA MUDA) DAN PUPUK N TERHADAP PERTUMBUHAN DAN PRODUKSI TANAMAN TOMAT (Lycopersicum esculentum Mill)
}

\author{
Mira Restida, Sarno \& Yohannes Cahya Ginting \\ Jurusan Agroteknologi, Fakultas Pertanian Universitas Lampung \\ Jl. Prof. Soemantri Brodjonegoro, No. 1, Bandar Lampung 35145 \\ E-mail:mirarestida@gmail.com
}

\begin{abstract}
ABSTRAK
Tomat merupakan tanaman sayuran buah yang banyak dikonsumsi masyarakat karena memiliki kandunagn vitamin yang baik bagi tubuh. Namun produksitvitas tomat masih tergolong rendah. Salah satu penyebab rendahnya produktivitas tersebut yaitu pemupukan yang belum memenuhi kebutuhan tanaman, sehingga dilakukan upaya untuk meningkatkan produktivitas dengan cara mengkombinasikan pupuk kimia dengan pupuk organik yaitu asam humat dan $\mathrm{N}$. Asam humat merupakan hasil akhir dari dekomposisi bahan organik yang dapat digunakan sebagai pupuk. Penelitian bertujuan untuk mengetahui pengaruh pemupukan $\mathrm{N}$ dan asam humat, serta interaksi antara pupuk $\mathrm{N}$ dan asam humat terhadap pertumbuhan dan produksi tomat. Penelitian dilaksanakan di Rumah Kaca Fakultas Pertanian Universitas Lampung dengan menggunakan Rancangan Acak Lengkap (RAL) secara faktorial $2 \times 5$ dengan 3 kali ulangan. Faktor pertama adalah pemupukan $\mathrm{N}$, yaitu $\mathrm{N} 0=\operatorname{tanpa} \mathrm{N}$ dan $\mathrm{N} 1=$ $17,5 \mathrm{~g}$ Urea/tanaman. Faktor kedua yaitu pemberian asam humat dengan konsentrasi $0,50,100,150$, dan $200 \mathrm{mg} \mathrm{L}^{-1}$. Data yang diperoleh diuji homogenitasnya menggunakan uji Bartlett, aditivitas data menggunakan uji Tukey, dan untuk membedakan pengaruh asam humat digunakan uji polynomial ortogonal pada á $=0,05$ dan á $=0,01$. Hasil penelitian memperlihatkan bahwa pada perlakuan tanpa $\mathrm{N}$, asam humat meningkatkan indeks kehijauan daun, tetapi bila diberi $\mathrm{N}$ hubungannya tidak nyata terhadap indeks kehijauan daun dan meningkat secara kuadratik terhadap tinggi tanaman, serta meningkat secara linier terhadap jumlah buah per tanaman dan bobot buah per tanaman.
\end{abstract}

Kata Kunci: Asam humat, N, tomat (Lycopersicum esculentum Mill).

\section{PENDAHULUAN}

Tomat merupakan tanaman sayuran buah yang banyak dikonsumsi masyarakat karena memiliki kandungan vitamin yang baik bagi tubuh. BPS dan Direktorat Jendral Hortikultura mencatat produktivitas tomat di Lampung 8,22 ton/ha dan masih dibawah potensi hasil tomat. Salah satu penyebab rendahnya produktivitas tersebut adalah pemupukan yang belum memenuhi kebutuhan tanaman. Tanaman hortikultura khusunya sayuran dapat tumbuh baik pada keadaan tanah yang memiliki unsur hara yang cukup dan kandungan humus yang tinggi (Haryanto dkk., 2006).

Peningkatan kandungan humus dapat dilakukan melalui penambahan bahan organik seperti pupuk kandang, namun membutuhkan dosis yang tinggi, sehingga kurang ekonomis. Octarina dkk., (2007) telah membuktikan bahwa peningkatan pertumbuhan dan produksi tomat diperoleh pada pemberian pupuk kandang ayam 10 ton $\mathrm{ha}^{-1}$. Oleh karena itu, untuk meningkatkan produktivitas tanaman dengan cara yang lebih ekonomis, maka perlu mengkombinasikan pupuk kimia dengan pupuk organik yaitu pemberian asam humat.

Salah satu bahan yang dapat menghasilkan asam humat adalah batubara muda. Asam humat merupakan hasil akhir dari dekomposisi bahan organik. Asam humat dapat mempengaruhi pertumbuhan tanaman baik secara langssung maupun tidak langsung. Secara tidak langsung asam humat dapat memperbaiki sifat fisik, kimia, dan biologi tanah, sedangkan secara langsung asam humat berperan dalam proses metabolisme (Tan, 1991). Heil (2004) menyatakan bahwa pemberian asam humat secara langsung mampu meningkatkan proses metabolisme dalam tanaman melalui peningkatan laju fotosintesis. Peningkatan laju fotosintesis disebabkan oleh meningkatnya kandungan klorofil di daun (Ferrara dan Brunetti, 2010).

$\mathrm{N}$ merupakan unsur hara essensial yang berperan dalam meningkatkan kadar protein dalam tanaman dan berperan dalam pembentukan klorofil, sehingga dapat meningkatkan pertumbuhan tanaman (Sutejo, 2002). Usman (2010) melaporkan bahwa pemberian pupuk N 
dapat meningkatkan pertumbuhan dan hasil tanaman jagung manis, dan mampu meningkatkan jumlah daun pada tanaman lidah buaya (Noverita, 2005), serta jumlah buah per tanaman pada tanaman okra (Adil dkk., 2006).

Pengaruh pemberian asam humat terhadap pertumbuhan dan produksi telah dilaporkan beberapa peneliti, yaitu El-Ghamry dkk., (2009) menyatakan bahwa pemberian asam humat melalui daun dapat meningkatkan tinggi tanaman, jumlah cabang dan daun, jumlah polong per tanaman, serta berat 100 biji kacang faba. Selain itu, Salman (2005) melaporkan bahwa pemberian asam humat dapat meningkatkan produksi hasil dan kualitas tanaman semangka. Sarno dan Eliza (2012) mendapatkan bahwa pemberian asam humat dengan konsentrasi 0 dan $200 \mathrm{mg} \mathrm{L}^{-1}$ yang diikuti dengan pemberian Urea $120 \mathrm{mg} /$ pot dapat meningkatkan tinggi tanaman, jumlah daun, berat kering trubus, berat basah trubus, dan serapan $\mathrm{N}$ pada tanaman bayam, sehingga sangat memungkinkan apabila pemberian asam humat melalui penyemprotan pada daun dan pemupukan $\mathrm{N}$ dapat meningkatkan pertumbuhan dan produksi pada tanaman tomat.

\section{BAHAN DAN METODE}

Penelitian dilakukan di Rumah Kaca dan Laboratorium Ilmu Tanah Fakultas Pertanian Universitas Lampung pada April hingga Agustus 2013. Alat-alat yang digunakan adalah timbangan, cangkul, ayakan, polybag, dan alat-alat laboratorium untuk analisis, sedangkan bahan-bahan yang digunakan adalah batubara muda, tanah media tanam yang berasal dari Kebun Percobaan Politeknik Negeri Lampung, benih tomat varietas Karina, pupuk N (Urea), P (SP-36), K $(\mathrm{KCl})$, dan bahan-bahan kimia untuk mengekstrak asam humat.

Penelitian ini disusun secara faktorial $2 \times 5$ dalam Rancangan Acak Lengkap (RAL) dengan tiga kali ulangan. Faktor pertama adalah pupuk $\mathrm{N}$ yang berasal dari Urea yaitu $\mathrm{N} 0=$ tanpa $\mathrm{N}$ dan $\mathrm{N} 1=17,5 \mathrm{~g}$ Urea/ tanaman. Faktor ke dua adalah pemberian asam humat yaitu $\mathrm{H} 0=0 \mathrm{mg} \mathrm{L}^{-1}, \mathrm{H} 1=50 \mathrm{mg} \mathrm{L}^{-1}, \mathrm{H} 2=100 \mathrm{mg} \mathrm{L}^{-1}$, $\mathrm{H} 3=150 \mathrm{mg} \mathrm{L}^{-1}$ dan $\mathrm{H} 4=200 \mathrm{mg} \mathrm{L}^{-1}$. Data yang diperoleh diuji homogenitasnya menggunakan uji Bartlett, aditivitas data menggunakan uji Tukey, dan untuk membedakan pengaruh asam humat digunakan uji polynomial ortogonal pada á $=0,05$ dan á $=0,01$.

Proses ekstraksi asam humat dilakukan dengan Menimbang batubara sebanyak $100 \mathrm{~g}$, lalu dimasukkan ke dalam erlenmeyer $2 \mathrm{~L}$ sebanyak 6 buah. Kemudian ditambahkan $0,1 \mathrm{~N} \mathrm{NaOH}$ dan diaduk pada hotplate selama 2 jam. Setelah itu, diberikan $\mathrm{HCl} 6 N$ hingga $\mathrm{pH}$ menjadi 1-2, dan dibiarkan selama 24 jam agar berkoagulasi. Lalu dipindahkan ke dalam tabung sentrifus dan disentrifus pada putaran $6.000 \mathrm{rpm}$ selama 30 menit. Kemudian endapan (asam humat) dengan larutan beningnya (asam fulvat) dipisahkan ke dalam labu erlenmeyer $500 \mathrm{ml}$, lalu asam humat tersebut dicuci dengan menambahkan aquades sebanyak $200 \mathrm{ml}$, dan dikocok selama 5 menit sebanyak 5 kali. Setelah itu, asam humat dikering oven pada suhu $60^{\circ} \mathrm{C}$ dan disimpan dalam desikator. Selanjutnya menimbang asam humat sebanyak 50, 100, 150, $200 \mathrm{mg}$, lalu dimasukkan ke dalam erlenmeyer $2 \mathrm{~L}$ dan ditambahkan $250 \mathrm{ml} \mathrm{NaOH}$. Kemudian diletakkan pada hotplate, lalu diaduk dengan stirer pada suhu $70^{\circ} \mathrm{C}$ hingga larut sempurna. Hasil adukan tersebut dipindahkan ke dalam gelas beacker 2 $\mathrm{L}$, lalu diukur $\mathrm{pH}$-nya. Kemudian $\mathrm{pH}$-nya dinetralkan dengan $\mathrm{H}_{2} \mathrm{SO}_{4}$. Larutan tersebut dibuat sebanyak yang dibutuhkan.

Polybag berisi $10 \mathrm{~kg}$ tanah diberi $\mathrm{N}$ yang berasal dari Urea sesuai dengan perlakuan yaitu $17,5 \mathrm{~g}$ Urea/ tanaman dan ditanami benih tomat. Pupuk SP-36 sebanyak 10,5 g/tanaman dan $\mathrm{KCl}$ sebanyak $8,75 \mathrm{~g} /$ tanaman diberikan sebagai pupuk dasar. Tiap polybag ditanami 1 bibit tomat. Penyiraman dilakukan setiap hari pada pagi dan sore hari, dan penyiangan dilakukan jika ada gulma yang tumbuh disekitar tanaman. Aplikasi asam humat dilakukan dengan penyemprotan melalui daun sebanyak tiga kali, yaitu pada tanaman berumur 20, 40, dan 60 HST. Pemanenan dilakukan pada 80 HST saat tanaman menunjukkan keadaan matang secara fisiologis. Variabel yang diamati adalah tinggi tanaman, jumlah daun, indeks kehijauan daun, jumlah buah per tanaman, bobot buah per tanaman, dan bobot tomat per buah.

\section{HASIL DAN PEMBAHASAN}

Tabel 1 memperlihatkan bahwa semua variabel pengamatan yaitu tinggi tanaman, indeks kehijaun daun, jumlah buah per tanaman, dan bobot per buah dipengaruhi oleh interaksi antara asam humat dan $\mathrm{N}$, kecuali pada jumlah daun dan bobot tomat per buah. Pada konsentrasi asam humat 0,50 , dan $200 \mathrm{mg} \mathrm{L}^{-1}$, yang di pupuk $\mathrm{N}$ sangat nyata lebih tinggi dibandingkan tanpa $\mathrm{N}$ pada semua variabel, kecuali pada tinggi tanaman tanggapannya tidak nyata. Sedangkan pada konsentrasi asam humat 100 dan $150 \mathrm{mg} \mathrm{L}^{-1}$, yang di pupuk $\mathrm{N}$ lebih tinggi dibandingkan tanpa $\mathrm{N}$ pada variabel pengamatan tinggi tanaman, indeks kehijauan daun, jumlah buah per tanaman, dan bobot buah per tanaman. Hal tersebut membuktikan bahwa $\mathrm{N}$ dapat meningkatkan pertumbuhan dan produksi tanaman. Pernyataan ini 
Tabel 1. Pengaruh asam humat dan $\mathrm{N}$ terhadap pertumbuhan dan produksi tomat.

\begin{tabular}{|c|c|c|c|c|c|c|}
\hline \multirow[t]{2}{*}{ Perbandingan } & $\mathrm{TT}$ & JD & IKD & JBP & B BP & $\mathrm{BB}$ \\
\hline & \multicolumn{6}{|c|}{------- (F-Hit dan angka dalam kurung merupakan selisih (\%)) ------- } \\
\hline \multicolumn{7}{|l|}{ Perlakuan N } \\
\hline C1 : N0 vs N1 & $\begin{array}{l}6,28^{*} \\
(1,97)\end{array}$ & $\begin{array}{c}13,37 * * \\
(1,27)\end{array}$ & $\begin{array}{c}277,23 * * \\
(3,31)\end{array}$ & $\begin{array}{c}225,33 * * \\
(3,47)\end{array}$ & $\begin{array}{c}251,32 * * \\
(86,15)\end{array}$ & $\begin{array}{l}9.43 * * \\
(7.06)\end{array}$ \\
\hline \multicolumn{7}{|l|}{$\underline{\text { Konsentrasi Asam Humat }}$} \\
\hline $\begin{array}{l}\text { C2 : H-Linier } \\
\text { C3 : H-Kuadratik }\end{array}$ & $\begin{array}{l}29,24 * * \\
16,09 * *\end{array}$ & $\begin{array}{c}13,50^{* *} \\
1,07 \mathrm{tn}\end{array}$ & $\begin{array}{l}15,09^{* *} \\
23,47^{* *}\end{array}$ & $\begin{array}{l}24,00^{* *} \\
17,14^{* *}\end{array}$ & $\begin{array}{l}27.42 * * \\
33.72 * *\end{array}$ & $\begin{array}{c}6.12 * \\
19.29 * *\end{array}$ \\
\hline \multicolumn{7}{|l|}{ Interaksi $\mathrm{N} \times \mathrm{H}$} \\
\hline $\begin{array}{l}\mathrm{C} 4: \mathrm{C} 1 \mathrm{X} \mathrm{C}_{2} \\
\mathrm{C} 5: \mathrm{C} 1 \mathrm{X} \text { C3 }\end{array}$ & $\begin{array}{l}0,36 \text { tn } \\
9,60 * *\end{array}$ & $\begin{array}{l}0,02 \text { tn } \\
3,82 \text { tn }\end{array}$ & $\begin{array}{l}4,55^{*} \\
2,08 \mathrm{tn}\end{array}$ & $\begin{array}{l}8,17^{*} \\
0.12 \mathrm{tn}\end{array}$ & $\begin{array}{l}6.13^{* *} \\
0.74 \text { th }\end{array}$ & $\begin{array}{l}3.76 \mathrm{tn} \\
0.44 \mathrm{tn}\end{array}$ \\
\hline \multicolumn{7}{|c|}{ Tanggapan tanaman terhadap $\mathrm{N}$ pada konsentrasi asam humat } \\
\hline $0 \mathrm{mg} \mathrm{L}^{-1}: \mathrm{N} 0 \mathrm{vs} \mathrm{N} 1$ & 0 tn & - & $\begin{array}{c}100,76^{* * *} \\
(4,46)\end{array}$ & $\begin{array}{c}26,67^{* *} \\
(2,66)\end{array}$ & $\begin{array}{c}24.68 * * \\
(60,36)\end{array}$ & - \\
\hline $50 \mathrm{mg} \mathrm{L}^{-1}$ : N0 vs N1 & 0 tn & - & $\begin{array}{c}50,65 * * \\
(3,16)\end{array}$ & $\begin{array}{c}33,75^{* * *} \\
(3)\end{array}$ & $\begin{array}{c}46,95 * * \\
(83,27)\end{array}$ & - \\
\hline $100 \mathrm{mg} \mathrm{L}^{-1}: \mathrm{N} 0$ vs N1 & $\begin{array}{l}6,58^{*} \\
(4,50)\end{array}$ & - & $\begin{array}{c}32,41 * * \\
(2,53)\end{array}$ & $\begin{array}{c}33,75^{* *} \\
\text { (3) }\end{array}$ & $\begin{array}{l}51,57 * * \\
(87,27)\end{array}$ & - \\
\hline $150 \mathrm{mg} \mathrm{L}^{-1}: \mathrm{N} 0$ vs N1 & $\begin{array}{c}17,47 * * \\
(7,34)\end{array}$ & - & $\begin{array}{c}69,14 * * \\
(3,7)\end{array}$ & $\begin{array}{c}70.42 * * \\
(4,33)\end{array}$ & $\begin{array}{c}68.49 * * \\
(101)\end{array}$ & - \\
\hline $200 \mathrm{mg} \mathrm{L}^{-1}: \mathrm{N} 0$ vs N1 & $\begin{array}{c}1,30 \mathrm{tn} \\
(2)\end{array}$ & - & $\begin{array}{c}36,82 * * \\
(2,7)\end{array}$ & $\begin{array}{c}70.42^{* * *} \\
(4,34)\end{array}$ & $\begin{array}{c}66.77 * * \\
(99,3)\end{array}$ & - \\
\hline \multicolumn{7}{|c|}{ Tanggapan tanaman terha dap asam humat pada $\mathrm{N}$} \\
\hline N0 - H linier & - & - & $18.10 * *$ & $2.08 \mathrm{tn}$ & $3.81 \mathrm{tn}$ & - \\
\hline N0 - H kuadratik & $0,42 \mathrm{tn}$ & - & - & - & - & - \\
\hline $\mathrm{N} 1$ - H linier & - & - & $1.54 \mathrm{tn}$ & $30.08^{* *}$ & $29.75^{* *}$ & - \\
\hline N1 - H kuadratik & $25,27 * *$ & - & - & - & - & - \\
\hline
\end{tabular}

Keterangan: N0 = Tanpa N, N1 = 17,5 g N/tanaman, tinggi tanaman (TT), jumlah daun (JD), indeks kehijauan daun (IKD), jumlah buah per tanaman (JBP), bobot buah per tanaman (BBP), bobot individu tomat (BB), $* *=$ Sangat nyata pada taraf $5 \%$ dan $1 \%, *=$ nyata pada taraf $5 \%$, tn $=$ tidak nyata.

diperkuat oleh hasil penelitian yang ditunjukkan oleh Noverita (2005) bahwa N dapat meningkatkan jumlah daun pada tanaman lidah buaya dan jumlah buah pertanaman pada tanaman okra (Adil dkk., 2006), serta pertumbuhan dan hasil tanaman jagung manis Usman (2010).

Gambar 1 memperlihatkan bahwa dengan N, pemberian asam humat dapat meningkatkan tinggi tanaman secara kuadratik, jumlah buah per tanaman dan bobot buah per tanaman secara linier, sedangkan tanpa $\mathrm{N}$, asam humat dapat meningkatkan indeks kehijauan daun secara linier. Hal ini di duga karena $\mathrm{N}$ dalam tanah belum optimal sehingga klorofil dirangsang oleh asam humat. Hal ini membuktikan bahwa asam humat berperan baik dalam pertumbuhan dan produksi tanaman melalui peningkatan indeks kehijauan daun. Semakin meningkatnya indeks kehijauan daun, maka klorofil yang terbentuk semakin banyak. Semakin banyaknya klorofil yang terbentuk akan semakin meningkatkan laju fotosintesis, sehingga pertumbuhan dan produksi juga meningkat.

Hal ini sejalan dengan pernyataan Heil (2004) menyatakan bahwa pemberian asam humat mampu meningkatkan laju fotosintesis yang disebabkan oleh meningkatnya kandungan klorofil di daun (Ferrara dan Brunetti, 2010). Apabila N dalam tanah telah optimal, 


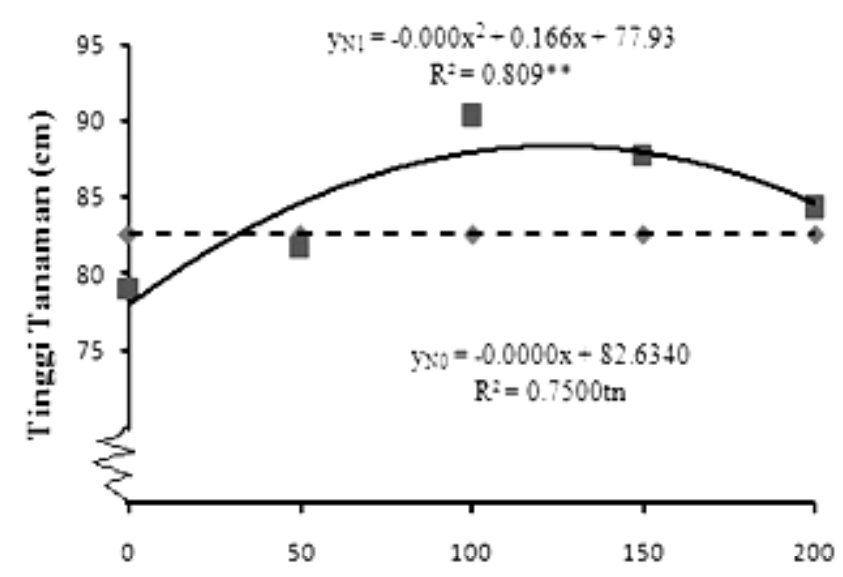

Konsentrasi Asam Humat (mg L-1)

(a)

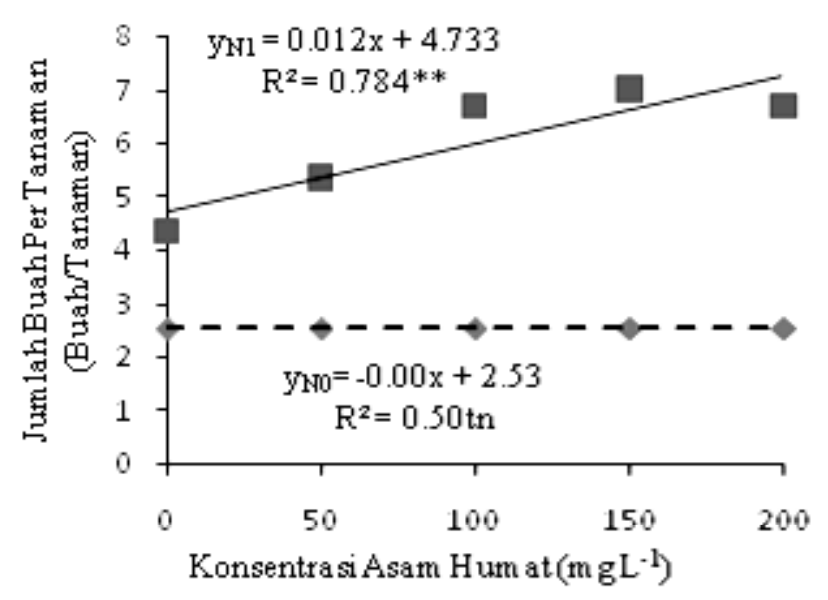

(c)

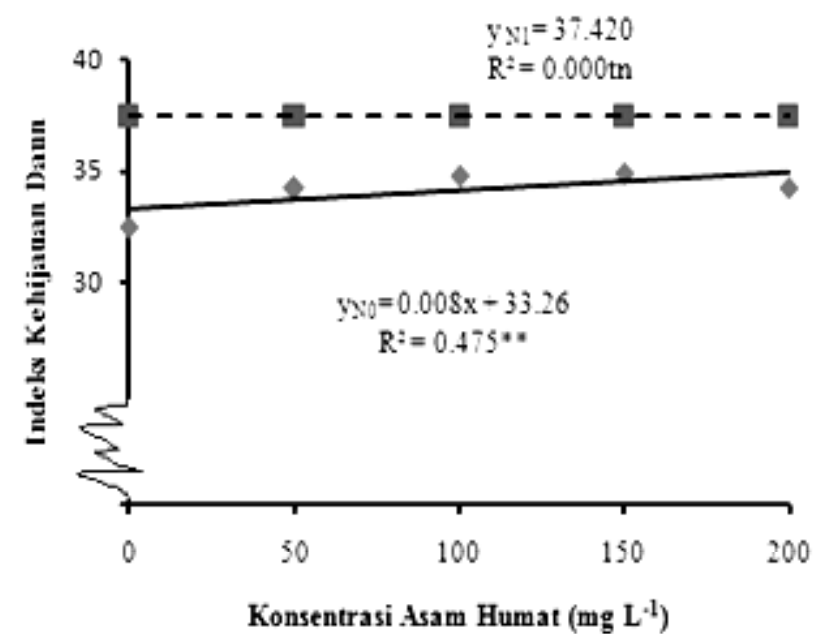

(b)

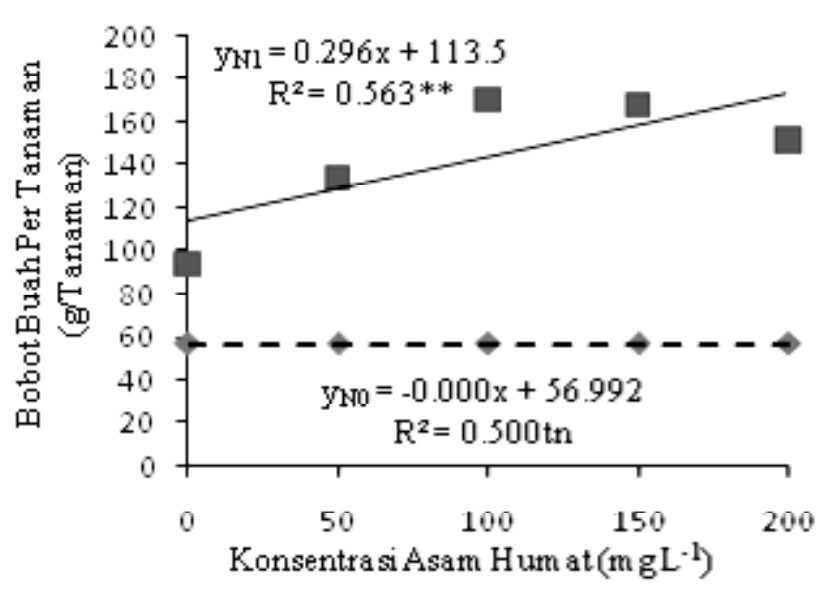

(d)

Gambar 1. Hubungan interaksi antara asam humat dengan pupuk $\mathrm{N}$ terhadap (a) Tinggi tanaman, (b) indeks kehijauan daun, (c) jumlah buah per tanaman, (d) bobot buah per tanaman. $\mathbf{Q}=$ Tanpa N (N0), $17,5 \mathrm{~g}$ N/tanaman (N1).

maka asam humat tidak menunjukkan pengaruh yang nyata, artinya penggunaan asam humat dapat meningkatkan efisiensi penggunaan $\mathrm{N}$.

\section{KESIMPULAN}

Berdasarkan hasil penelitian yang telah dilakukan, maka dapat disimpulkan bahwa variabel pertumbuhan dan produksi tanaman dipengaruhi oleh interaksi antara asam humat dan N. Pada tanpa N, tinggi tanaman, jumlah buah per tanaman, dan bobot buah per tanaman pengaruhnya tidak nyata, tetapi indeks kehijauan daun meningkat secara linier dengan meningkatnya pemberian asam humat. Bila diberi $\mathrm{N}$, dengan meningkatnya pemberian asam humat, tinggi tanaman meningkat secara kuadratik, sedangkan jumlah buah per tanaman dan bobot buah per tanaman meningkat secara linier, tetapi indeks kehijauan daun tidak berpengaruh. Oleh karena itu, perlu dilakukan penelitian lebih lanjut mengenai pemberian asam humat dan pupuk $\mathrm{N}$ terhadap pertumbuhan dan produksi tanaman dengan konsentrasi asam humat yang lebih tinggi ataupun lebih rendah.

\section{DAFTAR PUSTAKA}

Adil, H.W., Sunarlim, N., dan Roostika, I. 2005. Pengaruh tiga jenis pupuk nitrogen terhadap tanaman sayuran. Biodiversitas. 7(1) : 77-80. 
El- Ghamry, A.M. K.A. El-Hai and K.M. Ghoneem. 2009. Amino and humic acids promote growth, yield and disease resistance of faba bean cultivated in clayey soil. Aust. J. Basic Appl. Sci.3(2): 731-739.

Ferrara. G and G. Brunetti. 2010. Effect of the times of aplication of a soil humic acid on berry quality of table grape (Vitis vinifera L.) cv Italia. Spanish J. Agric. Res. 8(3): 817-822.

Haryanto, E., T. Suhartini, E. Rahayu, dan H.H. Sunarjono. 2006. Sawi dan Selada. Penebar Swadaya. Jakarta. $122 \mathrm{hlm}$.

Heil, C.A. Influence of humic, fulvic and hydrophilic acids on the growth, photosynthesis and respiration of the dinoflagelatte Prorocentrum minimum (Pavillard) Schiller. Abstract. Copyright (C) 2004 Elsevier B.V. All rights reserved.

Noverita. 2005. Pengaruh pemberian nitrogen dan kompos terhadap komponen pertumbuhan tanaman lidah buaya. Jurnal Penelitian Bidang Ilmu Pertanian. 3(3) : 95-105.
Octarina, V.A., Mulyati, dan Tejowulan, R.S. 2007. Respon Tanaman Tomat Terhadap Pemberian Pupuk Kandang Ayam dan Urea Terhadap Pertumbuhan dan Serapan N. J. Agroteksos. 17(1): 51-56.

Salman, S.R., S.D. Abou-Hussein, A.M.R. AbdelMawgoud and M.A. El-Nemr. 2005. Fruit Yield and Quality of Watermelon as Affected by Hybrids and Humic Acid Application. J. App. Sci. Res. 1(1): 51-58.

Sarno dan Eliza, F. 2011. Pengaruh pemberian asam humat dan pupuk $\mathrm{N}$ terhadap pertumbuhan dan serapan N pada tanaman bayam. Prosiding SNSMAIP III. Hal: 289-293.

Sutejo, M.M. 2002. Pupuk dan Cara Pemupukan. Penerbit Rineka Cipta. Jakarta. 177 Hlm.

Tan, K.H. 1991. Dasar-Dasar Kimia Tanah. Gajah Mada University Press. Yogyakarta. $295 \mathrm{Hlm}$.

Usman, M. 2010. Respon Berbagai Populasi Tanaman Jagung Manis (Zea mays saccarata Sturt) Terhadap Pemberian Pupuk Urea. J. Agroland. 17(2) : 138-143. 